\title{
Nacionalne manjine u etničkoj situaciji: ogled iz epistemologije društvenih znanosti
}

DOI: https://doi.org/10.11567/met.33.3.3

UDK: 323.15

Izvorni znanstveni rad

Primljeno: 04.02.2018.

Prihvaćeno: 28.03.2018.

\author{
Aleksandar Vukić \\ Institut za migracije i narodnosti, Zagreb \\ aleksandar.vukic@imin.hr
}

\section{SAŽETAK}

Polazeći od Luhmannove naturalizirane konstruktivističke epistemologije i interakcionističkih teorija situacije, razvija se pojam etničke situacije. Autor pokazuje kako operacije društvenih i psihičkih sistema proizvode, održavaju i transformiraju etničke situacije, kako definiranje situacije motivira ponašanje njezinih sudionika i kako dijalektika promatrača (nekog stupnja promatranja) i situacije generira opise, diskurse i poglede na svijet. Na temelju sistemsko-teorijskih pretpostavki razvija se teorija promatranja etničke situacije kao pojma konstruiranog promatračevim teorijskim aparatom.

KLJUČNE RIJEČI: država, promatranje, situacija, opis, etnička situacija, etničke skupine, nacionalne manjine, promatrač, manjinsko-većinska situacija

\section{UVOD}

Pojmovi u društvenim znanostima prije svega su promatrački aparati koji određuju što promatramo $i$ kako to činimo. ${ }^{1} \mathrm{U}$ središtu je ovoga istraživanja međusobni odnos promatrača, promatranja i predmeta promatranja (etničkih skupina) u etničkoj situaciji. Ono se kreće u granicama epistemologije društvenih znanosti. Uvjerljivost pozitivističke vizije sociologije, po kojoj primjena jasno definiranih metodoloških postulata osigurava istinite spoznaje društvenog svijeta, uglavnom se povukla pred razložnim načelom da svaka sociologija mora razmatrati dijalektiku unutarnjeg $i$ vanjskog promatranja, to jest odnos značenja imanentnih promatranoj zajednici i sociološkog uvida te istraživačeva (promatračeva) prethodnog znanja koje izvire

Luhmannov pojam promatranja koji preuzimamo u ovome radu mnogo je širi od metodološkog postupka promatranja koji je uvriježen u društvenim znanostima. Njemački sociolog preuzeo ga je i donekle modificirao iz radova biologa Maturane i Varele. Ti autori promatranje i spoznaju ugrađuju u same temelje opstanka i razvoja živih sistema. Složeni društveni sistemi kojima se bavi Luhmann na temelju promatranja i komunikacije konstruiraju univerzume simbola i značenja, odnosno svoju situaciju u svijetu. 
iz njegove životne situacije i njegove teorije. S tim je u vezi i zastarijevanje spoznajne teorije koja polazi od razlikovanja mišljenje/bitak, spoznaja/predmet, subjekt/objekt. Njezino mjesto dijelom zaposjeda i »konstruktivistička naturalizirana epistemologija (Luhmann, 2011: 31) - detranscendentalizirana epistemologija koja se prije svega bavi fizičkim, biološkim, psihičkim i društvenim uvjetima spoznaje.

Od te Luhmannove, konstruktivističke epistemologije i interakcionističkih teorija polazi i ova analiza u pokušaju sadržajnog obogaćenja pojma »etnička situacija« - ključnoga pojma istraživanja međusobnog odnosa etničkih skupina s različitih promatračkih motrišta koja ih transformiraju u nacije i nacionalne manjine. Sociologija i (kulturna) antropologija nisu stvorile dovoljno razvijen okvir istraživanja etničkih i nacionalnih manjina koji bi omogućio da se taj fenomen cjelovito zahvati s motrišta tih znanosti. Vjerojatan razlog tomu jest i činjenica da su sociološka i antropološka istraživanja manjina tek ogranak etničkih studija (Eriksen, 2004: 210) usmjerenih na odnos između etničkih skupina i konstruiranje identiteta, a tek iznimno na odnos države prema etničkim skupinama, kojim se i formira manjinskovećinska situacija. To je prema Barthu (1969: 19) možda i glavni razlog nerazvijene sociološko-antropološke teorije o manjinama. Vjerodostojan opis etničke situacije pretpostavlja promatranje funkcije države kao organizacije koja koncentrira moć na određenom teritoriju i njezine uloge u oblikovanju etničke situacije. Svoju moć ona ostvaruje kroz mehanizme promatranja, nadgledanja, nadzora, imenovanja i kategoriziranja društvenih skupina i pojedinaca koji čine stanovništvo države. ${ }^{2}$

Prihvati li se Luhmannovo načelo po kojem se sistem konstruira i održava operacijom promatranja kroz procese razlikovanja i označivanja, onda se osobita pozornost posvećuje opisima i samoopisima promatrača (u situaciji i izvan nje) te njihovu logičkom grupiranju u sisteme klasifikacije ljudskih kolektiviteta, diskursa, pogleda na svijet i konstrukcije različitih identiteta. Iz takva pristupa nastaje temeljni istraživački program (metoda) sistemskog pristupa. U takvu teorijskom okviru spomenute transformacije etničkih skupina nisu posljedica kulturnih razlika među njima, nego je posrijedi spoznajni proces u kojem promatrači razlikovanjem proizvode različitost (Bateson, 1979: 99). Stoga je i ovaj rad usmjeren na procese unutarnjih i vanjskih razlikovanja koja promatraču omogućuju selekciju i svrstavanje objekata u klase i kategorije. Unutrašnji selekcijski mehanizmi jesu (etničke)

Podrobniji prikaz tih funkcija države vidjeti u radu Moć klasifikacije: klasifikacijske sheme i konstrukcija etničke strukture u Banskoj Hrvatskoj i Slavoniji (1785.-1860.) (Vukić, 2008). 
institucije, ono što M. Douglas (2001) naziva »legitimized social groups «, ${ }^{3}$ a izvanjski su klasifikacijske sheme i opisi različitih promatrača. Ako se kao konstitutivni čimbenik društvenog sistema uzima granica između njega i okolice, onda selekcijska uloga institucija postaje značajna. Institucionalne strukture mogu se promatrati kao oblici informacijske složenosti. Njima se pripisuje donošenje rutinskih odluka, rješavanje uobičajenih problema te obavljanje rutinskog mišljenja u ime pojedinca. Prošlo iskustvo smješteno je $\mathrm{u}$ institucionalna pravila i djeluje kao vodič onome što treba očekivati od budućnosti. Tu je na djelu za društvene sisteme ključna povratna sprega između obveza i očekivanja, koja je mehanizam povezivanja prošlosti i budućnosti konstitutivan za održavanje akcijsko-komunikacijskih sistema poput etničkih grupa ili nacija (Luhmann, 2001a; Douglas, 2001).

Temeljni se problem sistemsko-sociološkog pristupa sadržaju »etničke situacije«, a i ovoga istraživanja, može sažeti u pitanju: kako operacije društvenih i psihičkih sistema proizvode, održavaju i transformiraju etničke situacije? Na stranicama što slijede taj se problem razlaže na više pitanja koja su sva u domeni društvene epistemologije; prvo: što je promatračko motrište i kako se etničke skupine transformiraju (preobražavaju) u nacionalne manjine?; drugo: sociološki pojam situacije; treće: promatranje i etnička situacija; četvrto: uzajamno promatranje i konstrukcija identiteta; peto: izvanjski promatrač - država; šesto: EU kao izvanjski promatrač nacionalne države u etničkoj situaciji.

\section{DRUŠTVENA EPISTEMOLOGIJA}

Sociologija i kulturna antropologija dobro su pripremljene za ovu promjenu paradigme. Radovi Parsonsa (1949, 2011), Feyerabenda (1979), Khuna (1999), Alexandera (1982), Collinsa (1983), Flecka (1979), a napose Mary Douglas (2001) i Niklasa Luhmanna (2001a) svjedoče o dugotrajnom nastojanju na stvaranju epistemologije društvenih znanosti utemeljene u spoznajnoj teoriji koja uzima u obzir dostignuća fizike, biologije, kognitivnih znanosti i teorije sistema. U suvremenoj je znanosti pojam sistema nastao kao rezultat tendencije interdisciplinarnog izučavanja fenomena, kao pokušaj sinteze rascjepkanih znanstvenih disciplina. U tom smislu formuliraju se zajednički analitički pojmovi koji se upotrebljavaju u različitim disciplinama. To su pojmovi otvorenog i zatvorenog sistema, međusobnog proži-

\footnotetext{
Po Douglas, etničke skupine kao jednu od institucionaliziranih struktura društvenog poretka uputno je promatrati kao, prije svega, zajednice mišljenja koje razvijaju svoje načine mišljenja. Kako bi naglasili pluralističku narav modernosti, Berger i Luckmann upotrebljavaju pojam subuniverzum značenja.
} 
manja, izolacije i interakcije, centralizacije i decentralizacije. Uz pomoć tih pojmova organizira se sadržaj različitih podataka u smislene cjeline. Zbog takvih je visokih zahtjeva teorija društvenih sistema, kako to pokazuje Luhmann, superteorija s univerzalnim važenjem jer se odnosi na sebe samu i na suparničke teorijske sisteme. Da bi se mogla odnositi na sebe samu, ona mora imati vodeću diferenciju - sposobnost razlikovanja razlike - koja upravlja mogućnostima obrade informacija u teoriji. ${ }^{4}$ Temeljno razlikovanje u teoriji društvenih sistema jest: sistem - okolina.

Sociologija nije, niti bi trebala biti, znanost o ljudskim društvima, a pogotovo ne o konkretnim društvima. Za Luhmanna (2001a: 37) sociologija je znanost o društvenim sistemima podložnima opisu; zbog inherentnih osobina apstraktno-deduktivnih teorijskih sistema ta je znanost primjenjiva na sve konkretne slučajeve. No takvu određenju sociologije, domeće Luhmann (2001a: 38), »nije cilj da teoriju društva (zbog preopterećenosti premisama) isključi nego da je (sa sociološki još jasnijim premisama) uključi u opću teoriju sistema «.

Naravno, naturalizirana konstruktivistička epistemologija jednostavno zaobilazi razmatranja o korisnosti ili štetnosti interdisciplinarnosti u znanosti polazeći od premise da u korpusu znanja ne postoji instanca koja bi unaprijed mogla reći što je istinita ili lažna spoznaja. Na to pitanje može se odgovoriti samo kroz znanstvenu proceduru i komunikaciju u znanosti promatranoj kao društveni sistem.

Tako Feyerabend dokazuje da znanost nema superiorno motrište te da se moraju razmotriti i druge promatračke perspektive koje konstruiraju predmete znanstvene spoznaje. Za Parsonsa je društvena činjenica konstrukcija promatrača - skup teorijski integriranih pojmova primijenjenih u promatranju neke situacije. Kuhn je argumentirano upozorio na činjenicu da su općeprihvaćene znanstvene istine prije svega rezultat »dogovora« unutar društveno dominantne zajednice istraživača. Alexanderovo istraživanje logike društvenih znanosti usmjereno je na »krpanje« epistemoloških rezova nastalih zbog različitih socioloških perspektiva (razlikovanja inherentna sociološkoj tradiciji: odnosi mikro/makro; akter/struktura). ${ }^{5}$ Collinsov doprinos epistemologiji jest svojevrsno proširenje interakcionističkog pojma situacije na makrostrukture upućivanjem na povijesne i biografske elemen-

4 Tako je u teoriji evolucije kao primjeru superteorije vodeća diferencija koja kodira informacije $u$ teoriji ona između varijacije i selekcije.

5 Distinkcije koje su, promatrane iz današnje perspektive, nastale još u vrijeme konstituiranja sociologije. One su posljedica različitih pogleda na "prirodu « društva (individualističkoga, utilitarističkoga, kolektivističkoga...). Pojam situacije iznova je »otkriven « u vrijeme tzv. mikrosociološke revolucije osamdesetih i devedesetih godina prošlog stoljeća. 
te situacije. Kod Flecka i Douglas riječ je još uvijek o društvenoj konstrukciji znanstvenih činjenica. Činjenice ne postoje tamo negdje u svijetu čekajući da budu otkrivene, nego su one prije svega društveno konstruirane u zajednici istraživača koji se u borbi za svoju paradigmu nastoje izboriti za svoju definiciju stvarnosti. Kod Luhmanna je već riječ o razvijenoj teoriji promatranja koja uključuje pojmove znanosti kao društvenog sistema, promatrače prvog, drugog i n-tog stupnja, teoriju kao promatrački aparat, pluralizam perspektiva, okruženje sistema (odnosno situaciju) koje je uvijek kompleksnije od sistema, promatranje kao redukciju kompleksnosti te pojam situacije kao prostorno-vremenskog isječka stvarnosti koji zahvaća promatračeva pojmovna (teorijska) mreža. Ako prihvatimo da nema promatranja bez teorijskih pojmova, moramo usmjeriti pozornost na analizu načina na koji znanost promatra i konstruira svoje objekte u situaciji.

Svi predmeti promatranja jesu konstrukcije. Ali oni nisu puke maštarije, nego imaju uporište $u$ realnosti društvene situacije u kojoj se nalazi znanost kao sistem društva, a i pojedinačni znanstvenik/promatrač kao član »republike učenih « (Berger i Kellner, 1991: 62). Konstruiranu narav tzv. socioloških objekata i njihovu utemeljenost u situaciji pokazat ćemo na pojmovima etničnosti, etničke skupine i nacionalnih manjina. Svi ti pojmovi odnose se na isti objekt promatranja - skupine ljudi u određenoj promatranoj situaciji. Kod klasičnih sociologa Durkheima i Webera ti se pojmovi gotovo i ne razmatraju. U kratkom osvrtu u Privredi i društou Weber (1976) etničke skupine opisuje kao skupine koje se konstituiraju na temelju iracionalne ideje o izabranom narodu. Durkheim i Weber pod dojmom modernizacijskog procesa funkcionalne diferencijacije društva vide uglavnom klasne, staleške, profesionalne i teritorijalne strukture. Zašto se do prije pedesetak godina društvena situacija promatrala uglavnom kao odnos društvenih klasa u sistemu, a zašto od šezdesetih godina u središte dolazi pitanje identiteta društvenih skupina i proučavanje etničkih skupina, pitanje je za sociologiju znanja.

O teorijskome promatračkom aparatu ovisi kojim ćemo pojmovima opisati neku skupinu. Istraživanju položaja nacionalnih manjina u društvenom sistemu može se pristupiti s motrišta različitih znanstvenih disciplina. Demografska istraživanja na temelju popisa stanovništva, prije svega, proučavaju brojčane odnose između etničkih skupina u sistemu, kulturološku multikulturalnost/interkulturalnost te politološku dinamiku odnosa većine i manjine. Pravno-normativistički pristup razmatra koliko su zakoni o pravima nacionalnih manjina usklađeni sa zakonima u drugim zemljama ili s poveljama o ljudskim i manjinskim pravima koje donose nadnacionalne organizacije poput Ujedinjenih naroda ili Europske unije. 


\section{SOCIOLOŠKI POJAM SITUACIJE}

Razmatranje povijesti pojma društvene situacije omogućuje nam razvijanje referentnog okvira etničke situacije. Konkretnost, lokaliziranost, vremenska lociranost i broj sudionika ključni su elementi referentnog okvira od kojega počinje konstrukcija teorijskog pojma etničke situacije. Zbog zahtijevane konkretnosti od temeljne su važnosti kategorije prostora i vremena: kako ih akteri doživljavaju, kako ih dijele i organiziraju, što s njima čine i kako preko njih prepleću, križaju i koordiniraju svoja pojedinačna djelovanja.

Teorijska koncepcija etničke situacije koja se ovdje izlaže utemeljuje se u filozofskim pojmovima »situacije « (Sartre, 2006), »situacijske određenosti « $\mathrm{i}$ »sjedišta u životu « (Dilthey, 1980) te u mnogo većoj mjeri u sociološkim teorijama »društvene situacije« (Thomas i Thomas, 1928), Parsonsovu (1949) povezivanju pojma situacije i teorije djelovanja, »situacije licem-u-lice« Bergera i Luckmana (1992) i mikrosociološkim teorijskim orijentacijama i njihovim analizama situacije u kontekstu svakodnevnog života (Collins, 1983).

Prema Mertonovu (1995: 382-386) istraživanju pojma situacije, njega u sociologiji u razvijenome teorijskom obliku prvi upotrebljavaju Thomas i Znaniecki u studiji The Polish Paesant in America (1918-1920). Pojam etničke situacije nastaje u Sjedinjenim Američkim Državama neposredno nakon Prvoga svjetskog rata u ozračju donošenja antiemigracijskih zakona i sazrijevanja svijesti o problemima nedovoljno uspješne integracije etničkih skupina $u$ američkim gradovima i društvu. Društvene promjene $u$ američkim gradovima dvadesetih godina prošlog stoljeća uvjetovale su promjenu kuta promatranja među sociolozima, tako da se gotovo istodobno $u$ mnogim radovima pojavljuje pojam situacije. ${ }^{6}$ Tako će i promjene društvene situacije u šezdesetim i sedamdesetim godinama prošlog stoljeća voditi k općem prihvaćanju pojma »etnička skupina« u američkoj sociologiji. Novo u društvenoj situaciji tih godina jest snažno i neočekivano izražavanje etničke pripadnosti, koja postaje važan element društvenog djelovanja, lojalnosti pojedinaca i temelj njihovih kolektivnih prava. Etnička se skupina šezdesetih godina u SAD-u počela promatrati kao oblik socijalne organizacije

\footnotetext{
Tako i Park i Burgess (1921: 766), neovisno o Thomasu i Znanieckom, u svojoj raspravi o asimilaciji i amerikanizaciji uvode pojam definicije situacije: »Zajedničko sudjelovanje u aktivnostima implicira zajedničku definiciju situacije. U stvari, svaka pojedinčeva radnja, pa čak i cijeli moralni život ovise o definiciji situacije. Definicija situacije usmjerava i ograničava svaku moguću akciju, a redefinicija situacije mijenja karakter akcije.« Kao da u određenim situacijama neke ideje »vise u zraku« i odjednom se javljaju kod mnogih autora, kako je to još davno primijetila Suzanne Langer (1957).
} 
alternativan klasi, a etničnost kao forma identifikacije alternativna klasnoj svijesti (Brass, 1991: 19).

Pojam definicije situacije teorijski su razvili William Isaac Thomas i Florian Znaniecki i on je postao središnji pojam simboličkog interakcionizma. Glavna ideja jest da je čovjekovo djelovanje više povezano sa subjektivnim značenjem dane situacije nego s njezinim potpuno objektivnim vidovima. Pojedinci konstruiraju značenja situacije na temelju svojih iskustava, potreba i želja, a također i na temelju običaja i vjerovanja svoje društvene skupine. U svojoj glasovitoj formulaciji Thomas i Thomas (1928: 572) obrazlažu da »ako ljudi definiraju (opisuju) situaciju kao realnu, ona je realna po svojim posljedicama«. Po njihovu mišljenju, definicija situacije usko je povezana s interpretacijom normi i kulture. Do dezintegracije migrantskih etničkih skupina ne dolazi prije svega zbog promjene situacije, nego zbog promjene definicije situacije. Konstruiranje pojmova situacije i definicije situacije upravo u dvadesetim godinama u SAD-u dobra je ilustracija dijalektičkog odnosa promatranja i konkretne društvene situacije. Ti pojmovi nastaju iz interakcije multietničke situacije rastućih američkih gradova i jednoga europskog teorijskog pogleda na tu situaciju. ${ }^{7}$

Prema Collinsovu (1981) mišljenju, ponovno »otkriće« društvene situacije dogodilo se $\mathrm{u}$ vrijeme $»$ mikrorevolucija $« \mathrm{u}$ sociologiji. ${ }^{8}$ Od šezdesetih do devedesetih godina dvadesetog stoljeća Blumer (1969) razvija simbolički interakcionizam, Goffman (1974) dramaturški pristup, Berger i Luckmann (1992 [1966]) fenomenološki pristup, a Garfinkel (1967) etnometodologiju. Ti autori u vidokrug sociologije vraćaju osobnu kreativnost aktera, aktera s licem, neposrednu interakciju u situacijama licem-u-lice (uzajamne prisutnosti), definiciju situacije i »pregovaranje« o zajedničkom značenju, osobne biografije, svakodnevne simboličke razmjene, egzistencijalne tjeskobe i društveno značenje emocija.

Blumerov koncept situacije može se opisati kao dvostran, objektivan i interpersonalan. Ključ za razumijevanje odnosa između mentalnih konceptualizacija i akcije jest definicija situacije koju akteri skupa stvaraju. Akteri neprekidno interpretiraju i reinterpretiraju situaciju u kojoj oni pronalaze sebe u naporu da kreiraju i koordiniraju djelovanje s drugima.

Park je doktorirao u Njemačkoj, Znaniecki je bio poljski sociolog, a u formativnom dobu američke sociologije utjecaj Georga Simmela bio je osobito snažan.

8 Po Alexanderu i Gisenu (1987: 26), do te sociološke revolucije došlo je zbog možda pretjerane reakcije na Parsonsov funkcionalizam. Ta je revolucija, po njima, bila »najsnažniji i najkreativniji oblik mikroteoretiziranja u povijesti sociologije«. U tome je razdoblju predmet promatranja i središnja tema socioloških istraživanja postao svakodnevni život. 
Ključna ideja Garfinkelove etnometodologije jest ta da sudionici u društvenom životu $\mathrm{u}$ isto vrijeme $\mathrm{i}$ istim postupcima istodobno konstruiraju $\mathrm{i}$ opisuju svoje okružje ili situaciju (setting) koja tvori unutarnju refleksivnost - ekvivalenciju između proizvođenja i opisivanja interakcije. Djelovanje i jezična obrada tog djelovanja nisu odgovor na apriornu stvarnost, nego oni tu stvarnost konstituiraju. To je radikalna verzija Thomasove »definicije situacije «. Po etnometodolozima, elementi interakcije mogu se valjano razumjeti jedino u odnosu na ukupni kontekst situacije. No kod etnometodologa svaka situacija kao da nastaje ni iz čega. Utoliko ostaje bez odgovora, ili barem bez daljnjeg objašnjenja, pitanje odakle tolika uređenost i kontinuitet među situacijama, njihovo međusobno nadovezivanje i kumuliranje njihovih efekata (Berger i Luckmann, 1992 [1966]). Etnometodološke studije gotovo se nikada ne bave hijerarhijskim situacijama, u smislu da neki akteri raspolažu, a neki ne raspolažu sankcijama koje mogu osnažiti njihove definicije situacije.

Most od mikroteoretiziranja interakcionizma i etnometodologije k makroteoretiziranju čini Goffmanovo istraživanje interaktivnog poretka, koji on razumije kao zasebnu domenu društvene realnosti. Iz uključenosti aktera u konkretne situacije, iz njihovih definicija i međusobnog "pregovaranja izviru značenja koja se ne mogu svesti na institucionalne ciljeve ili očekivanja vezana uz uloge. Predmet Goffmanova rada prije svega su granične situacije, i otuda istraživanja stigme, azila, ludnica i bolnica. U središtu je njegove teorije metafora kazališta i izvedbe. Kulise, pozornica i publika, dakle situacija, ključne su za izvedbu. Goffman je itekako bio svjestan postojanja širih elemenata situacije od onih licem-u-lice te u kasnijim godinama razvija »analizu okvira situacije « u kojoj situaciju smješta u širi kontekst društvene strukture, povijesti i osobnih biografija.

Schütz, Berger i Luckmann uvode pojam biografske situacije. U svojim spisima o metodologiji društvenih znanosti Schütz (1970: 371-372) naznačuje fenomenološki program koji će poslije sociološki razviti Berger i Luckmann: »U svakom trenutku svojega svjesnog života ja se nalazim u svijetu, i moj položaj u njemu - u vremenu, prostoru, prirodi i, kako ćemo pokazati kasnije, kao čovjeka među ljudima - to kakvim se on meni predstavlja ja nazivam svojom situacijom u svijetu. Odnosno, ja se uvijek nalazim, kako se vole izražavati francuski egzistencijalisti, $u$ situaciji. No ta situacija ima svoju povijest, a određeni elementi te povijesti pojavljuju se isključivo kao elementi moje biografije. Svaka situacija u odnosu je s prethodnom iz koje se razvila.« 
Funkcionalizam je u obje svoje inačice, Parsonsovoj i Mertonovoj, razvio u mnogočemu dublje i teorijski razrađenije elaboracije pojmova društvene situacije i definicije situacije. Kada Parsonsa promatramo iz današnje perspektive, čini se da je jedan od njegovih glavnih doprinosa konstrukcija apstraktne pojmovne mreže koja bi trebala biti najširi teorijski okvir za usmjerivanje empirijskih istraživanja. No, slijedeći Kanta i Whiteheada, Parsonsov rad predstavlja i jedan od najsnažnijih napada na pozitivističku epistemološku poziciju u društvenim znanostima. Parsons pokazuje da su tzv. znanstvene činjenice prije svega skup pojmova logički integriranih u određeni referentni okvir, skup koji nastaje teorijski usmjerenim promatranjem objekata u situaciji. Drugi njegov doprinos, kako to pokazuju Lidz i Staubmann (2011: 8-12), jest elaboracija referentnog okvira kojom upozorava da je odnos akter - situacija paralelan odnosu organizam - okružje, tekst - kontekst i figura - pozicija (u šahu). ${ }^{9}$ Merton je polazeći od Thomasovih i Znanieckijevih istraživanja razvio skup integriranih teorija srednjeg opsega - teorije samoostvarujućeg proročanstva (self fulfilling prophecy), samorazarajućeg proročanstva (self destroing prophecy) i teoriju o nenamjeravanim i neočekivanim posljedicama djelovanja (unintended or unanticipated consequences). »Kriva definicija situacije potiče na ponašanje koje je utemeljeno $u$ pogrešnoj percepciji situacije za koju se drži da je istinita. Takva funkcionalna petlja rezultira vladavinom grešaka (Merton, 1968: 477). Poznata je priča o ekonomskoj propasti poljskoga i ruskoga plemstva, koje je iz romana francuskih autora stjecalo predodžbe o tome kako bi trebao izgledati život aristokracije. Za održavanje tako zamišljenog i prakticiranog životnog stila prihodi od zemlje nisu bili dovoljni, pa su se zaduživali kod etničke skupine koja se, zbog toga što joj nije bilo dopušteno da posjeduje zemlju, morala baviti novčarskim poslovima - Židova. Naravno da je posljedica bila mržnja prema onome tko poznaje i ispunjava želje (Žižek, 2002: 160-161).

Osebujan pogled na društvo razvija Simmel. Budući da izbjegava pojam društvo, isprva nije smatran sociološkim klasikom, no kako je s vremenom došlo do promjene paradigme (Kuhn, 1999) u sociologiji, on postaje ključni izvor za autore mikrosociološke orijentacije. Neki aspekti njegova rada snažno su utjecali i na Luhmanna. Za Simmela je društvo, kako je to pokazao Coser (1977), oznaka (ime) za određeni broj pojedinaca povezanih interakcijom. Krupnije strukture - obitelj, klan, država, grad i sindikat - tek su kristalizacije interakcije, premda mogu steći autonomiju i trajnost te se pojedincu nametnuti kao otuđene moći. Simmel promatra forme koje su u

O nedovoljnom korištenju spoznajnim mogućnostima teorije igara (posebno šaha) u društvenim znanostima vidjeti u Elias (2007). 
podlozi različitih ponašanja aktera $u$ društvenim situacijama i utemeljuje "geometriju društvenog života« koja je po definiciji znanost o prostornim odnosima. On na temelju svoje opće sociološke orijentacije pokazuje da se analiza društvene situacije može započeti od tri apstraktne kategorije: vremena shvaćenog kao svakodnevni život, društvenih formi - sukob/suradnja, nadređenost/podređenost i bliskost/distanca, te broja ljudi uključenih u neki odnos u društvenoj situaciji (analiza dijade, trijade i mase). Suvremeno u Simmela jest razlaganje društvenih struktura na situacije međuljudskih susreta i interakcije, što rezultira svojevrsnom desupstancijalizacijom društvenih ustanova.

Čini se da prikazana geneza pojma situacije u sociologiji upućuje na zastarjelost pojma »društvo « shvaćenoga kao stabilni konkretni entitet sastavljen od pojedinaca koji slijede vlastite interese i koji se mogu dovesti u ravnotežu pod uvjetom da dijele zajedničke vrijednosti (Tilly, 1999; Luhmann, 2011). Ti autori pokazuju da se takvo što u stvarnome svijetu teško može naći. Zato mislim da je apstraktniji pojam situacije heuristički plodniji. Navedeni autori značajno su pridonijeli obogaćenju sadržaja pojma situacije, ali u njezino razumijevanje nisu na pravi način uključili značenje promatranja i promatrača.

S druge strane, sistemska sociološka teorija kao promatrač razlikuje društveni sistem (interakcijski i komunikacijski) i njegovo okružje, odnosno situaciju. Aktere u društvenom sistemu može se promatrati kao pojedince ili kolektivitete. Aspekti sistema ličnosti uključuju i etničku pripadnost, tako da se pojedince može promatrati kao elemente društvenih skupina (etničkih). U procesu međusobnog promatranja pojedinci (etničke skupine) proizvode opise drugih skupina (etiketiranje, tipiziranje i stereotipiziranje) i samoopise. Zbog različitih kutova promatranja nastaju kolektivni subuniverzumi značenja - najčešće sukobljeni.

U etničke situacije uvijek su osim prisutnih sudionika uključeni i, kako to pokazuju Berger i Luckmann (1992 [1966]: 55-57), suvremenici, prethodnici i nasljednici. U situaciju su uključeni i promatrači drugoga reda, društveni sistemi koje Luhmann naziva organizacijama (primjerice država i Europska unija) ili diferencirani funkcijski sistemi - znanost, školski sistem, tržište i obitelj). Na neki način kolektivni i pojedinačni akteri posjeduju svijest o kompleksnosti svoje etničke situacije i na temelju toga usmjeruju svoje djelovanje. Iz njihove perspektive situacija može biti i resurs za ostvarivanje akterovih ciljeva. Predstavljajući sebe u etničkoj situaciji, akter pred publikom može isticati ili prikrivati određene vidove svojega identiteta (Giddens, 1984: 90). 
I na kraju, sociologija može i treba promatrati promatrače etničke situacije - organizacije i funkcijske sisteme, i to tako da promatra razlikovne kodove koje promatrači drugoga stupnja upotrebljavaju u svojemu promatranju. S motrišta trećeg stupnja, promatrači drugog stupnja također su dio etničke situacije. Proizvodeći svoje sociološke opise, i sama sociologija postaje dio situacije, kako za sudionike tako i za druge promatrače.

\section{PROMATRANJE ETNIČKE SITUACIJE}

U zajedničkoj knjizi Osobe koje nedostaju: kritika društvenih znanosti Mary Douglas i Steven Ney (2003: 13) izložili su ideju da su društvene znanosti aparati za promatranje drugih kultura. Pogrešni zaključci i interpretacije drugih kultura po njima su, prije svega, posljedica manjkavosti promatračkog aparata. Dijalektika odnosa između društvenih znanosti (antropologije i sociologije) i promatranoga (sociologa i aktera, antropologa i domoroca) čini os oko koje se okreće teorija promatranja. Promatranje i komunikacija utemeljuju se u razlikovanju. Znanost se nalazi u društvenoj situaciji, ona joj nije izvanjska, ona svijet promatra iznutra. Njezin razlikovni kod, medij u kojemu operira, jest istinito/neistinito znanje. Opisivanje promatranja neke situacije dano u znanstvenom izvještaju dalje se komunicira u društvenom sistemu znanosti, dakle $\mathrm{u}$ jednom isječku realnosti koji tvori znanstvenu situaciju.

Ključno za Luhmannovu paradigmu promatranja jest shvaćanje da ne postoji dominantna točka promatranja. Znanost ne može zauzeti motrište Boga, iako ga često pokušava zauzeti. ${ }^{10} \mathrm{Zbog}$ funkcionalne diferencijacije društva izdvajaju se i posebni promatrački aparati: znanost, država, masovni mediji i umjetnost. Iz različitih promatračkih perspektiva razvijaju se opisi, diskursi i pogledi na svijet organizirani i selekcionirani u teme. Sve može postati tema komunikacije u situaciji. Opisi i situacije čine strukturnu spregu društvenog sistema i okružja. Operiraju kao kružne autoreferencijalne i heteroreferencijalne strukture po modelu dvostruke hermeneutike - promatranje konstruira situaciju, a situacija konstruira promatrača. »Sociolog-promatrač može učiniti društveni život sebi dostupnim kao 'fenomen' za promatranje jedino ako se osloni na resurs vlastitog znanja o njemu, kojim ga on konstituira kao 'temu za istraživanje'« (Giddens, 1976: 161-162).

10 O moralno-etičkim posljedicama obogotvorenja znanosti prvi su, koliko mi je poznato, pisali Mary Shelley (Frankenstein or The Modern Prometheus, 1818.) u književnosti i Heinrich Rickert u filozofiji. Luhmannu u središtu pozornosti nisu moralno-etičke dvojbe povezane s tendencijama razvoja novovjekovne znanosti, već epistemološki problemi koji prije svega proizlaze iz diferenciranja znanosti kao zasebnoga hiperspecijaliziranog društvenog sistema. 
Paradigmu za promatranje društvene situacije i odnosa unutarnjeg i izvanjskog promatranja razvio je Luhmann (2001b):

a) Samopromatranje i opisivanje nekog sistema naziva se refleksijom.

b) Promatranje sistema koje provodi neki vanjski promatrač naziva se proizvođenjem jedinstva.

Iz toga slijedi:

c) U slučaju refleksivnog (samo)opisivanja riječ je o identitetu.

d) U slučaju vanjskog opisivanja riječ je o klasifikaciji.

Luhmann (2011: 872) smatra da je tek Saussure prepoznao diferenciju znaka i označenoga kao čisto semiotičku i odsjekao svaku izvanjsku referenciju. To znači da se i objekti promatranja mogu shvatiti samo kao komponente nekog razlikovanja, a ne kao nešto što važi iz samoga sebe, ali također i da time sva razlikovanja gube svoju neupitnu samorazumljivost i moraju se shvatiti kao kontingentni uvjeti promatranja i označivanja. A to znači da se samoopisivanje društva može preustrojiti s pitanja što na pitanje kako. Tada njegov problem nije što društvo jest, nego: kako se opisuje, tko ga opisuje i pomoću kojih razlikovanja. S motrišta Luhmannova određenja promatranja pokazuje se da je etnička situacija rezultat međuigre unutarnjih i izvanjskih promatranja i definiranja. Razlikovanje unutarnjeg i vanjskog definiranja omogućuje promatranje etničke situacije s nekoliko različitih motrišta, odnosno analitičkih razina. S motrišta promatrača drugog stupnja znanost može konstruirati i promatrati etničke situacije na razini uzajamne prisutnosti u uvjetima svakodnevnog života, na razini država, na razini međusobnog odnosa država ili globalno na razini nadnacionalnih tvorevina poput Europske unije. Takvu pristupu zadatak je pokazati kako se mikrosituacije transformiraju u makrosituacije i obratno. Drugi istraživački program jest promatranje promatrača i njihovih razlikovnih kodova, opisa, kategorizacija i klasifikacijskih sistema. Tada se mogu razumjeti mehanizmi kojima promatrački aparati koji imaju moć definiraju etničke situacije i procese kojima se ta »mikrofizika moći« manifestira u etničkim situacijama.

Iz toga slijedi Luhmannova metodološka uputa - promatraj promatrače i njihove opise situacije. »Promatrači često mogu bolje predvidjeti djelovanje na temelju poznavanja situacije nego na temelju poznavanja ličnosti, i u skladu s tim, njihovo opažanje često, ako ne pretežno, čak ne odgovara mentalnom stanju aktera (Luhmann, 2001a: 240). 


\section{UZAJAMNO PROMATRANJE U ETNIČKOJ SITUACIJI I KONSTRUKCIJA IDENTITETA}

Orijentacija i motivacija pojedinaca u »etničkoj situaciji« regulirana je spoznajnim, afektivnim i moralnim programima etničkih institucija. Ti programi proizvode i učvršćuju granice prema drugim etničkim skupinama te samim tim osnažuju etnički identitet. Spoznajni programi opskrbljuju pojedince znanjem o njima samima, znanjem o njihovoj vlastitoj skupini, o grupnom naslijeđu i povijesti (koja se katkad svodi na pojedine odabrane »aspekte prošlosti«) te znanjem o vrijednostima pojedinčeve skupine. Moralni program podrazumijeva postojanje osjećaja grupnih obveza, primjerice važnosti učenja etničkog jezika, prenošenja moralnih vrijednosti skupine potomcima, endogamije te solidarnosti s članovima vlastite etničke skupine. Afektivni program etničkog identiteta pokriva osjećaje privrženosti skupini. Stoga se i može tvrditi da su institucije, napose etničke, tvorci i čuvari znanja koja su njihovim članovima nužna da bi opstali kao skupina (Isajiw, 1988). Postojeća institucionalizirana unutarnja određenja mogu osigurati obranu od nametanja izvanjskih. Iskustvo kategoriziranja i klasificiranja može ojačati postojeći grupni identitet kroz pružanje otpora, reagiranje i ojačavanje granica.

No i izvanjsko kategoriziranje i klasificiranje istodobno čine i bitne dimenzije unutarnjeg određenja. ${ }^{11}$ Izvanjsko određenje, ono koje drugi primjenjuju na nas, nedvojbeno utječe na naše samoodređenje (Jenkins, 1996: 23). Ako se kao konstitutivni čimbenik etničke situacije uzima granica između dvije etničke skupine $u$ interakciji, tada postaje značajna selekcijska uloga institucija. Institucije su dakle selekcijski mehanizmi koji omogućuju da se jedno djelovanje nastavi na drugo, jedna komunikacija na drugu, da se nešto zapamti, a nešto zaboravi. Institucije svojim kategorizirajuće-klasificirajućim selekcijskim mehanizmima spajaju motive djelovanja i očekivanja te tako kroz tipiziranje ponašanja aktera u ulogama grade društvene strukture. Etničke skupine ne mogu postojati ako ne postoje i druge etničke skupine. One su prije svega posljedica dugotrajnih interakcija u etničkim situacijama. Stoga se, po Barthu (1969), etničnost može i treba definirati situacijski, što ovdje znači relacijski i transakcijski: ona se proizvodi i reproducira s ovu stranu etničke granice, na njoj i preko nje. Prema Barthu, »etničke skupine su kategorije pripisivanja i identificiranja kojima se služe sami akteri« (1969:

11 Proces određenja »nas« zahtijeva da se »oni« razlikuju i time razdvoje od »nas«, ili da se s »nama« kontrastiraju; grupna kategorizacija vjerojatno će teći, barem dijelom, kroz pozitivno ili negativno kategoriziranje drugih. 
10). Etničke skupine/institucije »rade« po načelu jednostavnoga binarnoga kodiranja. Osnovna se operacija kodiranja provodi kroz razlikovanje na osi »mi« $\mathrm{i} »$ oni«, koja povlači granicu između sistema i okoline. Daljnja manipulacija »objektima « u okolini sistema prepuštena je operativnim programima izvedenim iz temeljnoga koda. Iz dijalektike unutarnjih kodiranja i izvanjskih opisivanja razvija se identitet etničkih skupina. Izvanjski opisi - u obliku zdravorazumskih, znanstvenih i ideoloških diskursa te službenih statističkih popisa - izraz su refleksivne prirode modernoga društvenog poretka koji se reproducira stvarajući različite diskurse o samome sebi. Diskursi su tijesno povezani s načinima na koje su društva strukturirana i organizirana. Oni su ti koji formiraju osobne i kolektivne identitete. Diskurs kao poredak - strukturirani sklop diskurzivnih procedura - što se u kojoj etničkoj situaciji može reći, u kojem trenutku i na kojemu mjestu neki iskaz vrijedi kao istinit. Određuje što je vrijedno znanja i sjećanja, a što se može potisnuti i predati zaboravu (Foucault, 2007: 17-19). Nadalje, stalnom proizvođenju diskursa u modernim društvima (najčešće u pisanom obliku) svrha je razviti mehanizme uključivanja i isključivanja određenih skupina u društvenom sistemu.

\section{IZVANJSKI PROMATRAČ-DRŽAVA}

Izvanjski promatrač koji utječe na konstituiranje etničke situacije jest i moderna država. Država je organizacija koja ima legitimnu moć da promatra, nadgleda, prebrojava, kategorizira i klasificira stanovništvo i na taj način utječe na formiranje etničkih identiteta i preoblikovanje etničke situacije. Naime moderna etnička situacija, složena konfiguracija položaja i odnosa etničkih skupina, posljedica je djelovanja različitih državnih i ideologijskih aparata, ratova i etničkih sukoba. No ona je danas i kvalitativno drugačija od etničkih situacija koje su joj prethodile, i to iz dva razloga. Prvo, etnička situacija zadobila je svoj moderni oblik - postala je »većinsko-manjinska «zbog nastanka nacionalnih država. ${ }^{12}$ Tu nije posrijedi puki brojčani odnos, nego odnos moći. Država definitivno pripada nekome, ona je nečija nacionalna država.

Kako je već naglašeno, izvanjsko promatranje neke situacije ili sistema naziva se proizvođenjem jedinstva, dok se opisivanje promatranog objekta provodi klasifikacijom. Konstruirano jedinstvo svih pojedinaca, s motrišta moderne države, naziva se populacijom ili stanovništvom. Dok je u tradi-

12 »Većinsko-manjinsku situaciju « podrobno razmatra Eriksen (2004: 207-214) i zaključuje da je o njoj smisleno govoriti jedino u kontekstu nacionalne države. 
cionalnim društvenim sistemima temelj kategoriziranja/klasificiranja najčešće povezan $\mathrm{s}$ mjestom $\mathrm{u}$ prostoru, $\mathrm{u}$ modernim se društvenim sistemima klasifikacije izvode iz apstraktnog pojma »stanovništvo«, pojmljenoga kao skup svih pojedinaca na teritoriju države. Po načelima društveno prihvaćenih klasifikacijskih shema, ljudi se razlikuju prema boji kože, spolu, dobi, obrazovnom, vjerskom, etničkom ili profesionalnom statusu. Za modernu teritorijalnu državu europskog tipa granice imaju konstitutivno značenje. ${ }^{13}$ U okvirima određenih granica teritorij s vremenom postaje resurs i ekonomska vrijednost. Stanovništvo je jedna od funkcionalnih, posrednih oznaka za ljude koji nastanjuju državno područje. Drugi nazivi - građani, narod, državljani - odnose se na pojedine uloge koju stanovnici ispunjavaju. Tako je i narod samo jedna od uloga društvene skupine u društvenom sistemu, a uloge proizlaze iz određenih svojstava institucija. Država se u strukturnom spoju sa znanošću početkom 19. stoljeća nametnula kao »vrhovna instanca « promatranja, nadziranja, imenovanja, kategoriziranja i klasificiranja stanovništva. Na tragu Foucaultovih (1979) proučavanja »konstituiranja subjekta « Hacking (1986) prikazao je proces »izmišljanja ljudi« kroz imenovanje (etiketiranje) te mehanizme prisile koji osiguravaju da pojedinci i društvene skupine interioriziraju te etikete. Radeći na statističkim podacima iz 19. stoljeća o devijacijama i nadzoru nad devijantnim osobama, Hacking (1990: 3) pokazuje kako je sam moderni način etiketiranja konstruirao »mnogo više vrsta ljudi no što je svijet prije toga ikad vidio«. Statistički uredi u Europi počeli su oko 1820. izbacivati pravu lavinu brojeva. Praksa brojenja i klasificiranja i sama je stvorila mnoštvo novih podjela. Onako brzo kao što su izmišljene nove statističke, etničke, medicinske i rodne kategorije, tako su i te nove kategorije ljudi spontano ili pod prisilom prihvaćale nova pripisana im obilježja i živjele u skladu s njima. No istodobno se odvijao i suprotni proces koji je metodom logičke apstrakcije spajao lokalne etničke skupine u teritorijalne etničke zajednice ili, ako su uvjeti bili povoljni, u nacije.

Izvanjski opisi etničke situacije - u obliku zdravorazumskih, znanstvenih i ideoloških diskursa te službenih statističkih popisa - izraz su refleksivne prirode modernoga društvenog poretka koji se reproducira stvarajući različite diskurse o samome sebi. Diskursi su prisno povezani s načinima na koje su društva strukturirana i organizirana. Oni su ti koji formiraju osobne i kolektivne identitete. Nadalje, prema Foucaultu (1976: 21-23), svaka episteme (ili pogled na svijet) koja prevladava u nekom društvenom sistemu blisko je povezana s moći nad drugima, moći da se drugi promatraju,

13 O pojmu granice kao ključnog čimbenika socijalnoga konstruiranja prostora i vremena vidjeti podrobnije u: Vukić, 2002: 157-169. 
imenuju (etiketiraju), kategoriziraju i klasificiraju. Na Zapadu su moderne institucije i s njima povezani diskursi proizveli novo shvaćanje društvenih skupina i pojedinca (subjekta). Opisivanje čovjeka kao subjekta, doduše, vlada filozofskom tradicijom novoga vijeka, ali nipošto nije jedina semantička reakcija na strukturno uvjetovani individualizam moderne. Postoje i sasvim drukčije formirani interesi za znanstveno istraživanje čovjeka koji, usporedno sa subjektivizmom, postaju vidljivi od 18. stoljeća. Dolazi do statističkih istraživanja u kojima individua služi kao statistička jedinica. Novi pojam »populacije« koja se sastoji od pojedinaca zamjenjuje staro mišljenje o vrstama i rodovima. Znanost o čovjeku stupa na mjesto temeljnog sloja znanja, mjesto koje je prije toga bilo religijski zaposjednuto. Kako bi se mogla istaknuti pretenzija na znanstvenost, istraživanje - i u tome je sadržana uvjetovanost društvenom situacijom - mora polaziti od individuuma, ali istodobno ne smije uzimati u obzir njegovu uvijek konkretnu jedinstvenost te mora pokazivati zanimanje za statističke učestalosti, prosječne vrijednosti ili za raspon njihovih ekstremnih izraza. Ili Luhmannovim riječima: »U uvjetima modernog pogleda na svijet individuum se mora pretpostavljati - i ujedno neutralizirati, ako ne pomoću neke transcendentalne teorije redukcije, onda statistički« (Luhmann, 2011: 906-907).

\section{IZVANJSKI PROMATRAČPROMATRAČA - EUROPSKA UNIJA}

Europska unija kao promatrač trećeg stupnja promatra nacionalne države. Svojim institucionaliziranim postupcima promatranja i evaluiranja djelovanja promatranih, prije svega zemalja kandidata za članstvo, snažno utječe na promjene etničke situacije kroz različito definiranje te etničke situacije. Ta europska definicija situacije izravno mijenja i poimanje suvereniteta nacionalne države, konfiguraciju odnosa moći etničkih skupina, a posredno i njihov identitet.

Promatranje koje EU provodi nad zemljama kandidatima konstruiralo je sadašnju »manjinsko-većinsku situaciju« i polako priprema zemlje kandidate za ulazak u novi imperij ${ }^{14}$ u kojemu će se i sadašnja većina i sadašnja manjina naći u manjinskoj situaciji. Po izvornoj zamisli osnivača, ujedinjena Europa jest savez država, a ne savezna država. Ona svoje uporište od početka ima u ekonomskom jedinstvu i političkoj koordinaciji u sklopu konfederalnog sistema koji bi se mogao usporediti sa sistemom SAD-a do Građan-

14 U svojem snažnom angažmanu protiv ulaska Norveške u EU sociolog Galtung (1973) prvi je Europu nazvao supersilom koja ima tendenciju pretvaranja u imperij sličan SAD-u. O imperiju i mnoštvu vidjeti knjigu Hardta i Negrija Imperij (2010). 
skog rata. No njezina unutarnja heterogenost, uvjetovana nacionalno-državnim tradicijama njezinih članica, uzrokuje krupne probleme. Po svemu sudeći, Europska unija svojim će evolucijskim trendom krenuti smjerom polaganoga, gotovo "prirodnoga « gašenja suverenosti svojih nacionalnih država članica. Ako se potvrdi taj trend, sadašnje nacionalne države dobile bi status povijesnih regija, uz zadržavanje određenih oblika samosvojnosti, kao što je danas slučaj s njemačkim saveznim državama, Škotskom ili Katalonijom.

Tom trendu i pokušaju da se on institucionalizira kroz Europski ustav glavna su prepreka različite tradicije samoodređenja pojedinih europskih nacionalnih država i njihov odnos prema vlastitim etničkim manjinama. Očito je da modernizacijsko-globalizacijski trendovi otvaraju pitanja europskog identiteta, identiteta nacija i etničkih skupina koje je čine, što je sve povezano s pitanjem kapaciteta tog sistema da se održava kroz proširenje.

Položaj manjina u Europi ovisit će prije svega o smjeru transformacije Europske unije. O tome hoće li se ona u skoroj budućnosti raspasti, postati država naroda, zajednica država, konfederacija, labava ili centralizirana federacija, ili možda svojevrsni imperij, ovisit će položaj i identitet naroda i etničkih skupina koji su njezin sastavni dio. S motrišta naturalizirane konstruktivističke epistemologije i teorije društvenih sistema mnoštvo mogućih tendencija transformacije govori o kompleksnosti promatranog sistema (Europske unije). Njegova je struktura dakle načelno događajna - nepredvidiv je događaj stalno obnavljano polazište njegove strukturacije. ${ }^{15} \mathrm{U}$ Luhmannovoj teoriji događaj dobiva određeni inovacijski potencijal jer tvori element kompleksnih društvenih sistema koji se reproduciraju temporalizacijom svoje strukture. Temeljni obrazac te operacije jest tvorba događaja koji omogućuju nadovezivanje elemenata po shemi »prije-poslije«. Događaj je polazište strukturacije, što znači da se obrazac unutarnjih odnosa danog sistema preinačuje od događaja do događaja. Sistem se održava ponavljanjem novine odnosno individualnosti događaja; ona međutim već sljedećim događajem gubi tu kvalitetu singularne sadašnjosti (Luhmann, 2001a: 397-399).

Takvim se autoreferencijskim obratom pozornost premješta s održanja trajne naravi sistema na promjenljiv odnos sistema i svijeta, pri čemu sistem uz pomoć svojih promatračko-selekcijskih kodova funkcionalno reducira bezgraničnu kompleksnost svijeta. On naime izdvaja određen broj moguć-

15 U koncepciji događajne strukture sistema Luhmann (2001a: 393-396) smatra da u stvarnosti svaki novi događaj preispituje sve prethodne, a svaka sadašnjost bira sebi vlastitu prošlost. Tako je događaj u Luhmannovoj koncepciji društvenih sistema u potpunosti okrenut prema prošlosti, dok je njegova anticipativna snaga glede predstojećih događaja ništavna. Sve su opcije u tom smjeru otvorene jer je značenjski potencijal događaja beskonačan. 
nosti iz svijeta shvaćenoga kao ukupnost svih događaja i stanja, a ostale mogućnosti odbacuje u svoju okolinu. Granica između sistema i okoline, između unutra i vani, obilježava dakle ujedno i pad kompleksnosti - okolina je uvijek kompleksnija od sistema.

Teorija društvenih sistema pri pokušaju razumijevanja suvremenih društvenih sistema povećava svoju kompleksnost. Što su teorijski sistemi kompleksniji, veći su im izgledi da se nose s promjenljivom okolinom i da primjereno odgovore na njezine izazove; također, bogatije je strukturiran i isječak svijeta koji fokusiraju svojim promatranjem te je i redukcija koju provode univerzalnija. Prema tome, svijet postaje kompleksnim jedino iz perspektive stanovite teorije sistema koja ga nastoji preraditi u parametrima vlastite kompleksnosti. Empirijsko istraživanje etničke situacije, svaki njezin opis, s motrišta naturalizirane konstruktivističke epistemologije reformulira se u pitanja tko to govori, zašto to govori, s koje promatračke točke to čini te kakva definicija etničke situacije (opis) iz toga proizlazi. I zbog toga izgleda smislen istraživački program teorije društvenih sistema - promatraj promatrača.

Kulturni identitet postao je temeljem samoodređenja i budućeg razvoja malih naroda. Ovo posebno vrijedi za područje Europe, na kojemu kod većinskih i uglavnom titularnih naroda postoji tendencija da radi očuvanja nacionalno-državnih interesa teže postizanju etničke i kulturne homogenosti. U mnogim nacionalnim državama nastoje se osigurati prava manjina, no postoji bojazan da bi te manjine uz pomoć međunarodnog prava i politike mogle ostvariti samostalnost ili visok stupanj autonomije, što otvara mogućnost izbijanja secesijskih, vjerskih ili etničkih sukoba s krajnjim ciljem stvaranja novih nacionalnih država. Upravo su jačanje kulturnih partikularizama i afirmacija etničkih identiteta najveći protivnik ujednačivanju koje potiču tržišni racionalizam i globalna ekonomija utemeljena na novim tehnologijama.

Promjena etničke situacije - integriranje suverenih nacionalnih država u EU - automatski mijenja i konfiguraciju položaja i međusobnih odnosa etničkih skupina. Europski identitet postaje novootkriveni način samorazumijevanja mnogih Europljana. Kako to na temelju novijih istraživanja identiteta u EU-u zaključuje Rifkin (2006: 246), trendovi transformacije identiteta dobivaju na zamahu. Tako se prema izvješću Europske komisije trećina mladih (od 21 do 35 godina) u EU-u osjećala Europljanima, a 60\% posto građana osjeća »veliku ili priličnu vezanost« za EU. Vjerojatno je prerano na temelju sporadičnih istraživanja stavova o identitetu govoriti o tendenciji 
slabljenja tradicionalnih identiteta. Prije bi se moglo pretpostaviti da će u Europskoj uniji, koja je u procesu stalne transformacije, pojedinci u kriznim situacijama tražiti zaklon tradicionalnog identiteta, a u doba prosperiteta eksperimentirati s novim kozmopolitskim identitetima. Sociolog Zygmund Bauman (1996: 18) naznačio je mogući izlaz iz situacije identitetskih i etničkih sukoba u suvremenosti: »Ako se moderni 'problem identiteta' svodi na pitanje kako konstruirati identitet i održati ga, onda se postmoderni 'problem identiteta' prije svega svodi na pitanje kako izbjeći fiksirani identitet i ostaviti sebi što veći broj mogućnosti.« Može se zamisliti situaciju u kojoj bi mnogi stanovnici Europske unije postali Europljani i možda - kao što je to za sve pripadnike Europe priželjkivao Urlich Beck - kozmopolitski građani Europe za koje etnički i/ili nacionalni identitet neće biti bitno izvorište samoodređenja (Beck i Grande, 2007).

Civilizacija Zapada, odnosno Europa, izvorište je modernih tehnika promatranja svijeta, od kojih je jedna i znanost. Po Ortegi y Gasetu (2003: 46), jedna od tajni »europskog čuda« jest sposobnost očuvanja pluralnosti iz koje je i nastala, te slobode koja je omogućivala da se svijet promatra i opisuje iz različitih perspektiva. I sama kompleksnost europske etničke situacije izvire iz svojevrsnog multiverzuma tih promatračkih perspektiva i opisa. Zapadne ideje, tehnologija, oblici organiziranja društva i gospodarstva, načini vođenja modernih ratova, ideologije, ideologijski aparati prisile, ideja i organizacija moderne državne uprave s njezinim metodama klasificiranja, kategoriziranja i prebrojavanja stanovništva, promatranja i opisivanja drugih i stvaranje diskursa o njima - sve je to u određenom smislu utjecalo na oblikovanje i transformiranje etničke situacije Europe. Moderna etnička situacija složena je konfiguracija položaja i odnosa etničkih skupina i države u promatranome prostorno-vremenskom kontekstu. Tako na oblik i strukturu etničke situacije utječu procesi koji su rezultat odnosa moći u okviru europskog sistema država, odnosi u regiji koji se očituju kroz sukobe i ratove zbog granica i oblika države te međuetnički odnosi u samoj državi. Institucionaliziranjem djelovanja kolektivnih i pojedinačnih aktera na sve tri prostorno-vremenske razine stvaraju se etnički identiteti, dok se odnosi etničkih skupina kristaliziraju u etničkim strukturama. Položaji i identiteti kolektivnih i pojedinačnih aktera u etničkoj situaciji rezultiraju različitim definicijama etničke situacije. Upravo su te različite definicije situacije česti izvor sukoba, ali i dinamike u etnički složenim društvima. Borba da se nametne vlastita definicija etničke situacije ustvari je borba za hegemoniju u društvenom sistemu. Vladajuća etnička skupina posjeduje moć da namet- 
ne službenu definiciju etničke situacije. U radu na stvaranju i održavanju službene definicije njoj su na raspolaganju država kao organizacija i pravni poredak te njezini ideologijski aparati i organizacije zadužene za proizvodnju utemeljujućih mitova, izmišljanje tradicije i službene povijesti. Školski sistemi i državna propaganda mediji su kojima se »ispravna definicija etničke situacije« prenosi i usađuje pojedincima. Svijest pojedinaca o vlastitom položaju u etničkoj situaciji dio je dijeljene zalihe znanja u društvenim sistemima. Svatko u određenoj etničkoj situaciji zna što od koga može očekivati i na koji se način treba ponašati (Berger i Luckmann, 1992 [1966]: 60). Službena definicija situacije kroz zakone legitimira položaj etničkih skupina pozivajući se na povijest etničkih odnosa u sistemu. Pojedincima koji su nositelji brojnih društvenih uloga i etiketa koje su im pripisane etnička se situacija nadaje kao izvanjska sila koja ih unaprijed definira. Grubi scenarij za pojedinačne biografije najčešće je unaprijed pripremljen u etničkoj situaciji. Uz službenu i dalje opstaju i paralelne definicije etničke situacije, ali je njihov domet ograničen. Hoće li se paralelne definicije i priče moći čuti, ovisi o odnosima moći u sve tri prostorno-vremenske dimenzije te situacije. Društvene i povijesne znanosti, različite ideologije i brojne organizacije poput masovnih medija, nacionalne države ili Europske unije neprestano promatraju, nadgledaju i nadziru stanovništvo i jedni druge proizvodeći opise situacije našega mjesta i vremena u svijetu. Opisi se slažu u diskurse, a oni čine episteme, odnosno Weltenschauung epohe. S motrišta teorije sistema, promatranje etničkih skupina u društvenom sistemu razvija se na razlikovnom kodu inkluzija-ekskluzija (Luhmann, 2011: 73), kao odnos većine i manjine. »Većinsko-manjinska « situacija koja određuje položaj neke etničke skupine u sistemu konstruira se kroz promatranje, kategoriziranje i klasificiranje stanovništva koji počinju u vrijeme modernizacije, i to u liberalnodemokratskim modelima upravljanja i vladavine. Naime pojam manjine i većine pojavljuje se tek $\mathrm{u}$ procesu razvijanja ideja broja, predstavničke vladavine i izbornog prava od 18. stoljeća u zemljama u kojima se odigrala demokratska revolucija (Appadurai, 2008). 


\section{ZAKLJUČAK:UVJETI PROMATRANJA I KONSTRUIRANJA ETNIČKE SITUACIJE}

Izloženi nacrt teorije promatranja, promatrača i etničke situacije jedan je od mogućih pristupa etničkim skupinama, nacijama i nacionalnim manjinama. Njegova valjanost može se utvrditi ako se pokažu interpretativne sposobnosti tih složenih fenomena. Ako se složimo da se svijet, pogotovo suvremeni, ne spoznaje osjetilima ili tako što se u njega odlazi po podatke, već je uvijek posredovan nekim medijem prijenosa ili širenja, onda se razumnim čini program - promatraj promatrača. ${ }^{16}$

Bitno epistemološko pitanje koje postavlja rad jest: otvaraju li se polazeći od pojma etničke situacije mogućnosti teorijski utemeljenijih istraživanja i interpretacija etničkih odnosa? Za početak, predloženi istraživački program može se prikazati u obliku sheme koja zorno prikazuje odnose promatrača i etničke situacije; promatrača i promatranih, te promatranih promatrača. Pokazuje kako se konstruiraju situacije, što znači biti situiran u situaciji, što čini promatrač, a što čini promatrani.

Slika 1. Shematski prikaz teorije promatranja, promatračâ i etničke situacije

Figure 1. Schematic representation of observation theory, observers and ethnic situation

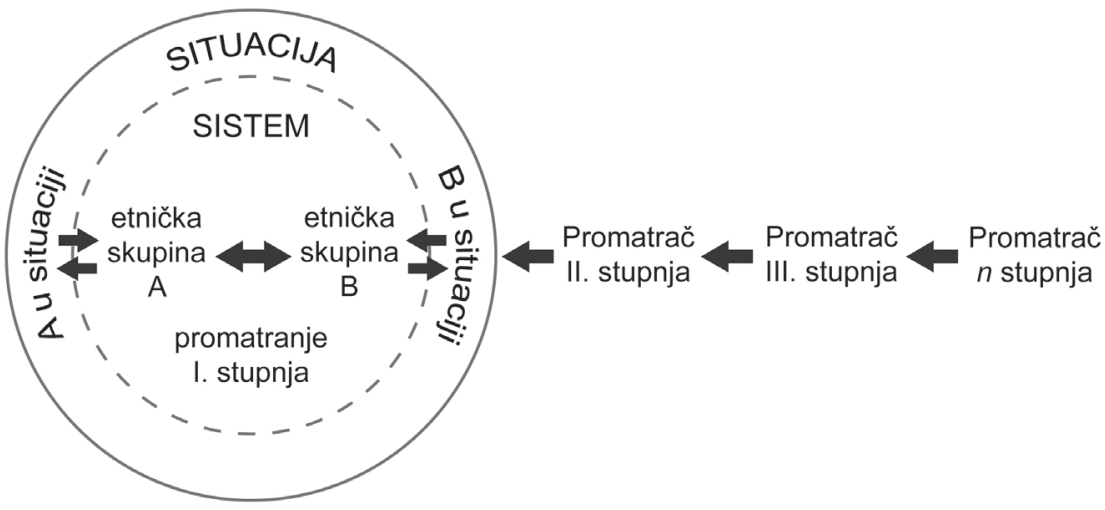

Shema se može tumačiti s motrišta teorije društvenih sistema ili pak s motrišta naturalizirane konstruktivističke epistemologije. Pritom valja na-

16 Pitanje je isplati li nam se potegnuti primjerice preko pola Balkana kako bismo na Kosovu prebrojavali Srbe i Albance ili ih ispitivali što misle jedni o drugima. Bolje je pokušati dešifrirati mrežu simbola i značenja u koji su zapleteni njihovi životi u njihovoj etničkoj situaciji. A o tome nam mnogo toga mogu reći već stvoreni opisi te situacije. Samo je potrebno upitati se tko to vidi, tko to govori i zašto to govori. 
glasiti da u shemi nije riječ o teleološkim ili hegemonskim odnosima između promatrača, jer nitko u suvremenom i kompleksnom društvenom sistemu ne može pretendirati na zauzimanje povlaštene točke promatranja. Stoga shema ilustrira temporalne odnose - jedno prije ili poslije, tj. situaciju da svaki promatrač uvijek biva i promatran.

Ako se shema promatra sa stajališta teorije društvenih sistema, promatrač prvog stupnja jest nacionalna država koja svojim selekcijskim i klasifikacijskim mehanizmima konstruira etničku situaciju i istodobno proizvodi opis te situacije. Europska unija kao promatrač promatrača prvog stupnja (nacionalne države), dakle kao promatrač drugog stupnja, to može činiti samo tako da i nacionalnu državu smjesti u etničku situaciju. Tada se kao promatrač drugog stupnja može pitati je li definicija etničke situacije koja se promatra (primjerice hrvatske) u skladu s civilizacijskim standardima, svjetonazorom ili, zašto ne, i interesima Europske unije. Promatrač trećeg stupnja, primjerice Srbin ili Hrvat iz Slovenije, može promatrati promatrača drugog stupnja i pitati se zašto u Sloveniji kao članici Europske unije pripadnici njegove etničke skupine nemaju status nacionalne manjine, kada ga Slovenci imaju u Hrvatskoj ili Srbiji. Promatrač četvrtog stupnja, primjerice sociolog znanstvenik koji se bavi etničkim studijama, u svoja promatranja etničke situacije, razložno, mora uključiti prethodna promatračka motrišta koja čine etničku situaciju. Naravno, i njegova je promatračka pozicija podložna nečijem promatranju.

U ovoj je točki trenutak da se prijeđe na tumačenje sheme s motrišta naturalizirane konstruktivističke epistemologije. Očigledno je da je promatrač prvog stupnja znanstvenik-autor teksta, koji vidi ono što može vidjeti svojim promatračko-teorijskim aparatom. Rezultat je neki tekst ili opis. Promatrač drugog stupnja jest urednik koji odlučuje kojim će recenzentima tekst biti poslan na čitanje (promatranje). Recenzenti su promatrači trećeg stupnja koji se bave promatračima prethodnih stupnjeva. Nakon recenzije promatrač prvog stupnja pojavljuje se u ulozi promatrača četvrtog stupnja jer promatra svoj tekst očima recenzenta. Ako tekst bude objavljen, pojavljuju se mogući čitatelji kao promatrači petog stupnja, koji se poslije mogu referirati na opise promatrača prethodnih stupnjeva ili se čak odlučiti na objavljivanje teksta koji pobija prethodni tekst ili ulazi u dijalog njim. Broj promatrača teorijski može biti beskonačan. Tu je na djelu temeljno načelo društvenih sistema - povećanje kompleksnosti.

Pojam etničke situacije omogućuje razmatranje etničkih odnosa u prostoru i vremenu. U svijesti sudionika etničke situacije uvijek postoji pitanje što će o određenom postupku misliti i reći prostorno često udaljeni proma- 
trač (što će misliti, reći ili učiniti EU, SAD ili Rusija ako mi svojoj manjini napravimo ovo ili ono). Vrijeme se u situaciji pojavljuje kao tradicija, sjećanje na prethodne međuetničke odnose, sukobe i ratove. Etnička situacija spaja prošlost i budućnost tako što se vrijeme pojavljuje kao prošla sadašnjost, sadašnja sadašnjost i sadašnja budućnost situacije.

Posebno se poticajnim smjerom budućih istraživanja s motrišta konstruktivističke epistemologije pokazuje uvođenje i elaboriranje ideje broja. Brojevi (sudionika u promatranoj situaciji), kako je to pokazao Appadurai (2008), kao konstituirajući čimbenik liberalnodemokratskog pogleda na svijet, ključni su za razumijevanje odnosa manjina i većina u suvremenom svijetu. On prije svega misli na važnost brojeva 1 i 0 . U liberalnom diskursu svijet je sastavljen od pojedinaca koji se pridodavanjem nula pretvaraju $\mathrm{u}$ stvarne ili zamišljene agregate (recimo, žene koje su završile fakultet, ili obitelji s više od troje djece, ili Albanci u Hrvatskoj). Brojevi su, kao što je poznato, u temelju vladajućega kapitalističkog i demokratskog sistema, ali su $\mathrm{u}$ različitim etničkim situacijama povezani s biološkim osnovama društva. Strah da će se manjinska skupina brže razmnožavati od većinske demijurg je, kako to Apadurai pokazuje, mnogih predatorskih identiteta. Jedan od važnih pokretača srpskoga nacionalističkog pokreta u osamdesetim godinama prošlog stoljeća bio je strah da će Albanci postati većina u Srbiji.

S brojevima je povezan i sistemski razlikovni kod »inkluzija « - »ekskluzija«. Jedan vid isključivanja i uključivanja normalna je posljedica funkcionalne diferencijacije modernoga društvenog sistema. Tako i teorija Mary Douglas (2004) izložena u Čistom i opasnom (upravo zato što je apstraktna) može naći primjenu u tumačenju etničkih odnosa u situaciji. Teorija se temelji na dvije ideje: važnosti klasifikacija, razlikovanju »nas «, koji smo unutra, i »njih«, koji su vani, i teorije opasnosti (rizika). Sve izvire iz toga kako ljudi objašnjavaju sukobe, nevolje i nesreće. Svaka nesreća obično nalazi političko objašnjenje - prokazuje onoga tko je odgovoran za ono što se događa. Kada Francuz nema posla, krivi su Arapi, ne zato što su Arapi, nego zato što su opasni jer se nalaze na krivome mjestu. Kao što je zemlja u vrtu samo zemlja, a kada se nađe za kuhinjskim stolom, prljavština (Douglas, 2004). 


\section{LITERATURA}

Alexander, J. (1982). Theoretical Logic in Sociology: Positivism, Presuppositions, and Current Contoversies. Berkeley: University of California Press.

Alexander, J. i Giesen, B. (1987). From reduction to linkage: The long view of the micromacro debate, u: J. Aleksander, B. Giesen, R. Münch i N. Smelser (ur.). The MicroMacro Link. Berkeley: Univesity of California Press, 1-42.

Appadurai, A. (2008). Strah od malih brojeva. Beograd: Biblioteka XX vek.

Barth, F. (1969). Introduction, u: F. Barth (ur.). Ethnic Groups and Boundaries: The Social Organization of Boundaries of Culture Difference. Oslo: Universitets, 9-38.

Bateson, G. (1979). Mind and Nature: A Necessary Unity. New York: Dutton.

Bauman, Z. (1996). From pilgrim to tourist or: a short history of identity, u: S. Hall i P. Du Gay (ur.). Questions of Cultural Identity, London: Sage, 18-36.

Beck, U. i Grande, E. (2007). Cosmopolitan Europe. London: Polity.

Berger, P. L. i Kellner, H. (1991). Sociologija u novom ključu. Niš: Gradina.

Berger, P. L. i Luckman, T. (1992 [1966]). Socijalna konstrukcija zbilje. Zagreb: Naprijed.

Blumer, H. (1969). Symbolic Interactionism: Perspective and Method. Englewood Cliffs: Prentice-Hall.

Brass, P. (1991). Ethnicity and Nationalism: Theory and Comparison. London: Sage.

Collins, R. (1983). Sociological Theory. San Francisco: Josey Bass.

Collins, R. (1981). On the microfoundations of macrosociology, American Journal of Sociology, 86 (5): 984-1015.

Coser, L. A. (1977). Masters of Sociological Thought: Ideas in Historical and Social Context. New York: Harcourt Brace Jovanovich.

Dilthey, W. (1980). Zasnivanje duhovnih nauka. Beograd: Prosveta.

Douglas, M. (2001). Kako institucije misle. Beograd: Samizdat B92.

Douglas, M. i Ney, S. (2003). Osobe koje nedostaju: kritika društvenih nauka. Beograd: Samizdat B92.

Douglas, M. (2004). Čisto i opasno. Zagreb: Algoritam.

Elias, N. (2007). Što je sociologija? Zagreb: Antibarbarus.

Eriksen, T. H. (2004). Etnicitet i nacionalizam. Beograd: Čigoja štampa.

Feyerabend, P. (1979). Against Method. London: Verso.

Fleck, L. (1979). The Genesis and Development of a Scientific Fact. Chicago: University of Chicago Press.

Foucault, M. (1976). The History of Sexuality. Harmondsfort: Penguin.

Foucault, M. (1979). Discipline and Punish: the Birth of the Prison. Harmondsforth: Penguin.

Foucault, M. (2007). Security, Territory, Population: Lectures at the Collège de France, 197778. New York: Springer.

Galtung, J. (1973). The European Community: a Superpower in the Making. London: Harper Collins.

Garfinkel, H. (1967). Studies in Ethnomethodology. Cambridge: Polity Press. 
Giddens, A. (1976). New Rules of Sociological Method: Apositive Critique of Interpretative Sociologies. New York: Basic Books.

Giddens, A. (1984). The Constitution of Society: Outline of the Theory of Structuration. Cambridge: Polity Press.

Goffman, E. (1974). Frame Analysis: An Essay on the Organization of Experience. New York: Harper and Row.

Hacking, I. (1986). Making up people, u: T. Heller, M. Sosna i D. Wellbery (ur.). Reconstructing Individualism: Autonomy, Individuality, and the Self in Western Thought. Stanford: Stanford University Press, 222-236.

Hacking, I. (1990). The Taming of Chance. Cambridge: University Press.

Hardt, M. i Negri, A. (2010). Imperij. Zagreb: Multimedijalni Institut, Arkzin.

Isajiw, W. (1988). Ethnic identity retention, u: R. Breton i sur. (ur.). Ethnic Identity and Equality. Toronto: University of Toronto Press, 34-91.

Jenkins, R. (1996). Social Identity. London - New York: Routledge.

Khun, T. (1999). Struktura znanstvenih revolucija. Zagreb: HSD - Naklada Jesenski i Turk.

Langer, S. (1957). Philosophy in a New Key. Cambridge - London: Harvard Univesity Press.

Lidz, V. i Staubmann, H. (2011). Introduction, u: T. Parsons (ur.). Actor, Situation and Normative Patterns: An Essay in the Theory of Social Action. Munster: LIT Verlag, 5-30.

Luhmann, N. (2001a). Društveni sistemi. Sremski Karlovci - Novi Sad: Izdavačka knjžarnica Zorana Stojanovića.

Luhmann, N. (2001b). Znanost društva. Zagreb: Politička kultura.

Luhmann, N. (2011). Društvo društva. Zagreb: Breza.

Merton, R. K. (1968). Social Theory and Social Structure. New York: Free Press.

Merton, R. K. (1995). The Thomas Theorem and The Matthew Effect, Social Forces, 74 (2): 379-424, doi: https://doi.org/10.2307/2580486

Ortega y Gasset, J. (2003). Pobuna masa. Zagreb: Golden marketig.

Park, R. i Burgess, E. (1921). Introduction to the Science of Sociology. Chicago: University of Chicago Press.

Parsons, T. (1949). The Structure of Social Action. New York: Free Press.

Parsons, T. (ur.) (2011). Actor, Situation and Normative Patterns: An Essay in the Theory of Social Action. Munster: LIT Verlag.

Rifkin, J. (2006). Europski san: kako europska vizija budućnosti polako zasjenjuje američki san. Zagreb: Školska knjiga.

Sartre, J. P. (2006). Bitak i ništo: ogled iz fenomenološke ontologije. Zagreb: Demetra.

Schütz, A. (1970). Reflections on the Problem of Relevance. New Haven: Yale University Press.

Tilly, C. (1999). Suočavanja sa društvenom promenom. Beograd: Filip Višnjić.

Thomas, W. I. i Thomas, D. (1928). The Child in America: Behavior Problems and Programs. New York: Knopf.

Thomas, W. I. i Znaniecki, F. (1918-1920). The Polish Peasant in Europa and America. Chicago: University of Chicago Press. 
Vukić, A. (2002). Granice europskog akcijskog prostor-vremena, u: S. Mežnarić (ur.). Etničnost $i$ stabilnost Europe u 21. Stoljeću. Zagreb: IMIN - Naklada Jesenski i Turk, 157-169.

Vukić, A. (2008). Moć klasifikacije: klasifikacijske sheme i konstrukcija etničke strukture u Banskoj Hrvatskoj i Slavoniji (1785.-1860.), Migracijske i etničke teme, 24 (1-2): 31-48.

Weber, M. (1976). Privreda i društvo. Beograd: 1976.

Žižek, S. (2002). Sublimni objekt ideologije. Zagreb: Arkzin. 


\section{National Minorities in an Ethnic Situation: an Essay in Epistemology of Social Sciences}

\section{Aleksandar Vukić}

\section{SUMMARY}

The fundamental problem of a systematic sociological approach to the issue of "ethnic situations" and of this research may be summarised as the following question: how do the operations of social and psychological systems generate, maintain, and transform ethnic situations? In this paper, the problem is divided into several issues, all belonging to the domain of social epistemology: first, what is an observation point and in what way do ethnic groups transform into national minorities?; second, the sociological concept of a situation; third, observation and ethnic situation; fourth, mutual observation and identity construction; fifth, an external observer - the state; sixth, the EU as an external observer of the national state in an ethnic situation.

Starting from Luhmann's principle according to which a system is constructed and maintained through observation, using the processes of differentiation and signification, the paper pays special attention to the descriptions and self-descriptions of the observer (both within the situation and beyond), and their logical grouping in the systems of classification of human collectivities, discourses, world views and constructions of different identities. Such an approach is the source of the basic research programme (method) of a systematic approach, in which the mentioned transformations of ethnic groups are not a consequence of cultural differences between them, but arise from a cognitive process in which the observers produce differences by means of differentiation.

The concepts in social sciences are first and foremost observational devices determining what we observe and how we do it. This research focusses on the mutual relationship between observers, observation and observation subjects (ethnic groups) within an ethnic situation. It is within the limits of epistemology of social sciences. The persuasiveness of a positivist vision of sociology, according to which the application of clearly defined methodological postulates ensures true understanding of the social world, has generally retreated in the face of a reasonable principle stating that every branch of sociology must consider the dialectics of internal and external observation. That is, the relationship between the meanings immanent in an observed community and the sociological insight, and the researcher's (observer's) prior knowledge that emerges from their life situation and their theory. Related to this issue is the obsolescence of the theory of knowledge that starts from differentiation between the concepts of opinion/being, knowledge/object, subject/object. Its place is partly occupied by the "constructivist naturalised epistemology" - a detranscendentalised epistemology that primarily deals with physical, biological, psychological and social conditions of knowledge.

All subjects of observation are constructions. However, they are not mere fantasies, but have a foothold in the reality of the social situation in which science as a system of society is found together with the individual scientist/observer as a member of the "republic of scholars" (Berger and Kellner, 1991: 62). The concepts of ethnicity, ethnic group and national minorities discussed in the paper show the constructed 
nature of the so called sociological objects and their foundation in the situation. All of these concepts refer to the same object of observation - groups of people in a particular situation being observed.

Consideration of the history of the social situation concept allows us to develop a reference framework for the ethnic situation. Concreteness, location, timing and the number of participants are the key elements of the reference framework serving as the starting point for the construction of a theoretical concept of ethnic situation. Due to required concreteness, the categories of space and time are essential: how the actors perceive them, how they share and organise them, what they do with them, how they use them to overlap, converge and coordinate their individual actions.

A systematic sociological theory as an observer distinguishes between a social system (interactive and communicative) and its environment, i.e. the situation. Social system actors may be seen as individuals or collectivities. Aspects of a personality system also include ethnicity, so individuals may be seen as elements of (ethnic) social groups. During the process of mutual observation, individuals (ethnic groups) generate descriptions of other groups (labelling, typing, stereotyping) and self-descriptions. Due to different angles of observation, collective subuniverses of meaning are formed - mostly conflicting ones.

The situation also includes second-level observers, the social systems which Luhmann refers to as organisations (e.g. the state, the European Union) or differentiated functional systems (science, school system, market, family). In a way, collective and individual actors possess awareness of the complexity of their ethnic situation and direct their actions accordingly. From their perspective, the situation can also be a resource for achieving the actor's goals.

Sociology can and should analyse the observers of ethnic situations - organisations and functional systems, by analysing the differentiation codes that second-level observes use in their observation. Looking from a third-level perspective, second-level observers are also part of the ethnic situation. By generating its sociological descriptions, sociology itself becomes part of the situation both for participants and for other observers.

The notion that there is no dominant point of observation is essential to Luhmann's observation paradigm. The functional differentiation of society causes the emergence of special observation devices: science, the state, mass media, art. Descriptions, discourses and world views arising from different observation points are organised and selected into topics. Anything can become a topic of communication in a situation. Descriptions and situations make up a structural union of the social system and environment. According to the double hermeneutic model, they operate as circular selfreferential and hetero-referential structures - observation constructs the situation, while the situation constructs the observer.

Objects of observation can only be understood as components of differentiation, not as something that is meaningful for itself. All distinctions lose their unquestionable self-evidentness and must be understood as contingent conditions of observation and signification. That means that society's self-description can be redirected from the question of what to the question of how. In that case, the problem is not what society is, but how it is described, who describes it and by which distinctions. From the viewpoint of Luhmann's definition of observation, it is evident that the ethnic situation results from the interplay between internal and external observations and 
definitions. The distinction between the internal and external definition enables the observation of an ethnic situation from several different points of view or levels of analysis. From the perspective of a second-level observer, science can construct and observe ethnic situations at the level of mutual presence in everyday life, at state lev$\mathrm{el}$, at the level of state relations or globally at the level of supranational entities such as the European Union. The aim of such an approach is to show how micro-situations are transformed into macro ones and vice versa. Another research programme includes the observation of observers and their differentiation codes, descriptions, categorisation and classification systems. They allow for the understanding of mechanisms used by the observational devices wielding power to define the ethnic situations and processes through which the "micro-physics of power" is manifested in ethnic situations.

From this follows Luhmann's methodological instruction - observe the observers and their descriptions of a situation.

The orientation and motivation of individuals within an "ethnic situation" is regulated by cognitive, affective and moral programmes of ethnic institutions. These programmes cause and deepen the divides separating them from other ethnic groups, thus consolidating their ethnic identity. Cognition programmes provide individuals with knowledge of themselves, knowledge of their own group, group heritage and history (which sometimes comes down to certain selected "aspects of the past") as well as knowledge of the values of the individual's group. The moral programme implies the existence of group commitments, for example the importance of learning the ethnic language, of passing on moral values to the descendants, endogamy and solidarity with members of one's own ethnic group. The affective program of ethnic identity "covers" the feelings of attachment to a group. Therefore, it can be argued that institutions, especially ethnic ones, are the creators and guardians of knowledge needed by their members to survive as a group. Existing institutionalized internal definitions can provide defence against the imposition of external ones. The experience of categorisation and classification can strengthen the existing group identity by providing resistance, reactions and deepening the divides.

The modern state is another external observer that influences the constitution of an ethnic situation. The state is an organisation holding legitimate power to observe, oversee, count, categorise and classify the population, and thus influence the formation of ethnic identities and the transformation of the ethnic situation. The modern ethnic situation, a complex configuration of ethnic group's positions and relationships, is a result of operation of various state and ideological devices, wars and ethnic conflicts. However, today it differs in terms of qualitative features from the ethnic situations that had preceded it, and for two reasons. First, the ethnic situation took on its modern form of the "majority/minority" due to the emergence of national states. It does not come down to a mere numerical relationship, but to a relationship of power. The state definitely belongs to someone, it is somebody's national state.

The European Union as a third-level observer watches the national states. With its institutionalised procedures for observing and evaluating the activities of the observed, primarily the candidate countries, it strongly influences the changes of the ethnic situation by providing different definitions of it. Additionally, the European definition of a situation directly changes the understanding of the sovereignty of the national state, the configuration of power relationships between ethnic groups, and indirectly their identity. 
The very complexity of the European ethnic situation arises from a multiverse of these observational perspectives and descriptions. Western ideas, technology, forms of organisation of society and economy, ways of waging modern wars, ideologies, ideological devices of coercion, ideas and organisation of modern state administration with its methods of classifying, categorising and counting the population, observing and describing others and creating discourses about them - all of these have in a sense influenced the shaping and transformation of the European ethnic situation. A modern ethnic situation is a complex configuration of the position and relationship between ethnic groups and the state in the spatial-temporal context observed.

The presented draft of the theory of observation, observers and ethnic situation serves as a possible approach to ethnic groups, nations and national minorities. Its validity can be determined if the interpretative capabilities of these complex phenomena are proven. If we agree that the world, especially modern, is not perceived by senses or by entering it to obtain data, but is always mediated by some means of transmission or dissemination medium, then the programme of observing the observer seems to make sense. An important epistemological question posed by the paper is the following: does starting from the notion of ethnic situation open a possibility of more theoretically based research and interpretation of ethnic relations?

KEY WORDS: state, observation, ethnic situation, ethnic groups, national minorities, observer 